Our Nature (2010) 8: 219-224

\title{
Effect of High Temperature on Survival, Growth and Feed Conversion Ratio of Nile Tilapia, Oreochromis niloticus
}

\author{
N.P. Pandit* and M. Nakamura \\ Sesoko Station, Tropical Biosphere Research Center, University of the Ryukyus, Sesoko 3422, Motobu, Okinawa \\ 905-0227, Japan \\ *E-mail: panditnp@hotmail.com \\ Received: 25.08.2010, Accepted: 09.10.2010
}

\begin{abstract}
This study was conducted to investigate the effect of high water temperature on survival and growth performance of Nile tilapia. Two age groups of female Nile tilapia ( 9 and 50 days after hatching) were reared at $27,32,35$ and $37^{\circ} \mathrm{C}$ water temperatures for $45-60$ days. At the end of treatment, the mean survival, total weight, total length, daily growth rate and food conversion ratio of both age groups of fishes were significantly reduced at 35 and $37^{\circ} \mathrm{C}$ compared to 27 and $32^{\circ} \mathrm{C}(\mathrm{p}<0.05)$. It was concluded that water temperature ranging from $27-32^{\circ} \mathrm{C}$ seemed to be the most effective for rearing of Nile tilapia juveniles and fries, and higher temperature $\left(>32^{\circ} \mathrm{C}\right)$ results in slow growth, reduce feeding efficiency and increase mortality. This study also demonstrated the possible impact of global warming on natural fishery resources.
\end{abstract}

Key words: High temperature, Nile tilapia, juveniles, fry.

\section{Introduction}

Temperature is one of the environmental factors with greatest influence on the growth performance of animals. Being coldblooded animal, fish is affected by the temperature of the surrounding water which influences the body temperature, growth rate, food consumption, feed conversion and other body functions (Britz et al., 1997; Azevedo et al., 1998). Therefore, water temperature is a driving force in the fish life because its effects are more than any other single factor. Growth and livability in fish are optimum within a defined temperature range (Gadowaski and Caddell, 1991). Although short-term changes, such as weather conditions, may influence a fish for a day or two, but temperature has more predictable and seasonal effect.
Over the past few years, rising global temperatures have received much attention because of their worldwide impact on ecosystems. Global temperatures have warmed by approximately $0.6^{\circ} \mathrm{C}$ in the last century, a rate that has been unprecedented in the last 1000 years. The climate models referenced by the Intergovernmental Panel on Climate Change (IPCC, 2001) predicted that global temperatures are likely to increase by 1.4 to $6.4^{\circ} \mathrm{C}$ in this century. The effects of climate change on the sex ratios have already been inferred for some sea turtles with TSD (Kamel and Mrosovsky, 2006; Hawkes et al., 2007) and for a few fish species (Strüssmann et al., 1998). However, few studies have been conducted to forecast the potential threats of rising 
temperatures on growth and survival of natural fish population. The increase of a few degrees in water temperature can set off ecological changes that will affect most forms of aquatic life.

The Nile tilapia (Oreochromis niloticus), an African Cichlid, is a fish of great commercial interest. Their tropical and subtropical origins are clearly reflected in their thermal preferendum; these fish do not grow well at temperature below $16^{\circ} \mathrm{C}$ and cannot usually survive for more than a few days below $10^{\circ} \mathrm{C}$ (Chervinski, 1982), but they are remarkably tolerant of high temperatures, up to $40-42^{\circ} \mathrm{C}$ (Philippart and Ruwet, 1982). The effects of water temperature on growth and development of fish have been well documented for many species (Anelli et al., 2004; Chatterjee et al., 2004; Larsson and Berglund, 2005). For Nile tilapia, most studies used fish at a late stage of development when factors other than temperature may have permanent effects on growth characteristics (Hauser, 1977). No detailed information is available on the optimum temperature requirement of Nile tilapia fry. In this study, we examined the effect of different regimes of hightemperature on survival, growth performance and feeding efficiency of two different age groups of female Nile tilapia.

\section{Materials and methods}

This study was conducted in the Sesoko Station, Tropical Biosphere Research Center, University of the Ryukyus, Okinawa, Japan. Two sets of experiment were conducted using different age groups of female Nile tilapia (Oreochromis niloticus). In the first experiment, Nile tilapia juveniles of 9 days after hatching (dah) were stocked at the rate of 100 fish, in 50-L glass aquariums, each with a separate temperature regulation, aeration and recirculation system. Fish were reared at fixed water temperatures of $27^{\circ} \mathrm{C}$ (control), $32^{\circ} \mathrm{C}, 35^{\circ} \mathrm{C}$ and $37^{\circ} \mathrm{C}$ for 45 days. In the second experiment, Nile tilapia fries of 50 dah were stocked at the rate of 60 fish, in 50-L glass aquariums, and fish were reared at fixed water temperatures of $27^{\circ} \mathrm{C}$ (control), $35^{\circ} \mathrm{C}$ and $37^{\circ} \mathrm{C}$ for 60 days. A 2.0 $\mathrm{kW}$ immersion thermostatic heater with a temperature regulator (DEL THERMO, NITTO CO., LTD., JAPAN) was installed in each aquarium to maintain the preselected water temperatures. Experimental water temperatures were attained gradually by heating water at a rate of $5^{\circ} \mathrm{C} /$ day in order to avoid thermal shock. Both experiments were conducted in a completely randomized design (CRD). Fish were fed on a granulated commercial diet (C-700 and 1000 Kyowa Hakko Kogyo, Ltd, Tokyo, Japan) twice a day. Fish growth, survival and feed conversion ratio (FCR) were examined periodically throughout the experimental period. Water temperature (using 'As One' temperature meter, SATO KEIRYOKI MFG, CO., LTD., JAPAN) and fish mortality were recorded daily throughout the experimental period. Data were analyzed statistically by analysis of variance (ANOVA) using SPSS (version 15.0) statistical software package (SPSS Inc., Chicago). All means were given with \pm 1 standard error (S.E.).

\section{Results and discussion}

The final body weight, total length, weight gain, survival rate, and FCR for all groups of Nile tilapia in the present study are given 
N.P. Pandit and M. Nakamura / Our Nature (2010) 8: 219-224

in tables 1 and 2. Similarly, the fortnightly growth trends of all groups of fish in different temperatures during treatment are given in figures 1 and 2 . In 9 dah group of fish, the survival rate was significantly reduced at $37^{\circ} \mathrm{C}(57 \%)$ compared to $27^{\circ} \mathrm{C}$ $(96 \%), \quad 32^{\circ} \mathrm{C}(96 \%)$ and $35^{\circ} \mathrm{C}(95 \%)$ $(\mathrm{p}<0.05)$, whereas, there was no significant difference among $27^{\circ} \mathrm{C}, 32^{\circ} \mathrm{C}$ and $35^{\circ} \mathrm{C}$ $(p>0.05)$. In 50 dah group of fish, the survival rate was significantly reduced at $35^{\circ} \mathrm{C}(91 \%)$ and $37^{\circ} \mathrm{C}(80 \%)$ compared to $27^{\circ} \mathrm{C}(96 \%)(\mathrm{p}<0.05)$. In both experiments, most fish mortality took place during the first and last week of the experiment. In the present study, growth performance of Nile tilapia reared at $27,32,35$ and $37^{\circ} \mathrm{C}$ was temperature dependent. In both experiments, the final body weight, total length and daily weight gain were significantly reduced at 35 and $37^{\circ} \mathrm{C}$ compared to 27 and $32^{\circ} \mathrm{C}(\mathrm{p}<0.05)$ (Tabs. 12). At the end of the treatment, the mean body weight was extremely low in $37^{\circ} \mathrm{C}$ treated groups $(\mathrm{p}<0.05)$; however, no abnormalities was observed. These results support the earlier findings that growth and survival of fish are optimum within a defined temperature (Gadowaski and Caddell, 1991).

The acceptance response for the diet in the fish varied in a remarkable way with the experimental temperatures. All age groups of fish at $37^{\circ} \mathrm{C}$ in the present study fed slowly, compared with all other temperatures. Highly significant effects of temperature $(\mathrm{P}<0.05)$ on feed consumption and FCR were observed. Feed consumption increased with increasing temperature until $32^{\circ} \mathrm{C}$. Food conversion ratio differed between groups $(p<0.05)$ and decreased at the 35 and $37^{\circ} \mathrm{C}$ (Tabs. 1-2). The results of this study also revealed that the high water temperature above $32^{\circ} \mathrm{C}$ significantly reduced the survival, growth and feeding efficiency of the Nile tilapia. Watanabe et al. (1996) reported $25^{\circ} \mathrm{C}$ to be the optimum temperature for nutrient digestibility in tilapia, O. niloticus (L.) and common carp, Cyprinus carpio.

$O$. niloticus is known to tolerate high temperatures, up to $40-42^{\circ} \mathrm{C}$ (Philippart and Ruwet, 1982). However, the optimum temperature for feeding, growth and reproduction is between 26 and $30^{\circ} \mathrm{C}$ (Hauser, 1977). The present study clearly showed that the temperatures above $32^{\circ} \mathrm{C}$ may significantly decrease the survival and growth rate of Nile tilapia. The reduced growth performance at 35 and $37^{\circ} \mathrm{C}$ could be attributed to the low food intake and high rate of gastric evacuation, as reported by Elliot (1972), who observed a positive correlation between water temperature and the rate of gastric evacuation in fish. It has been suggested that higher temperature accelerates the rate of passing digesting food materials through the intestinal tract, thus reducing the digestibility and assimilation of nutrients, signifying that at high temperature, physiological processes associated with digestion and nitrogen retention function are less efficient in fish. In the present experiment, we observed maximum growth of Nile tilapia at 27 and $32^{\circ} \mathrm{C}$ in relation with maximum feed consumption and better FCR as shown in table 2.

This study provides an insight into the thermal effect on survival, growth and feeding efficiency of fish. It provides clear evidence that even short-term exposure to 
N.P. Pandit and M. Nakamura / Our Nature (2010) 8: 219-224

Table 1. Effect of temperature on growth, survival and food conversion ratio of 9 dah group of Nile tilapia at the end of temperature treatment (45 days) (Mean \pm SE).

\begin{tabular}{lcccc}
\hline Parameters & $\mathbf{2 7}{ }^{\circ} \mathbf{C}$ & $\mathbf{3 2}{ }^{\circ} \mathbf{C}$ & $\mathbf{3 5}{ }^{\circ} \mathbf{C}$ & $\mathbf{3 7}{ }^{\circ} \mathbf{C}$ \\
\hline Total length (cm) & $4.7 \pm 0.0^{\mathrm{a}}$ & $4.7 \pm 0.0^{\mathrm{a}}$ & $4.5 \pm 0.0^{\mathrm{b}}$ & $2.5 \pm 0.0^{\mathrm{c}}$ \\
Total weight (g) & $1.8 \pm 0.0^{\mathrm{a}}$ & $1.8 \pm 0.0^{\mathrm{a}}$ & $1.5 \pm 0.0^{\mathrm{b}}$ & $0.6 \pm 0.1^{\mathrm{c}}$ \\
Growth rate (g/fish/day) & $0.04 \pm 0.0^{\mathrm{a}}$ & $0.04 \pm 0.0^{\mathrm{a}}$ & $0.03 \pm 0.0^{\mathrm{b}}$ & $0.01 \pm 0.0^{\mathrm{c}}$ \\
Survival (\%) & $96 \pm 0.0^{\mathrm{a}}$ & $96 \pm 0.0^{\mathrm{a}}$ & $95 \pm 1.0^{\mathrm{a}}$ & $57 \pm 3.2^{\mathrm{b}}$ \\
FCR & $2.3 \pm 0.0^{\mathrm{a}}$ & $2.2 \pm 0.0^{\mathrm{a}}$ & $2.5 \pm 0.0^{\mathrm{b}}$ & $3.2 \pm 0.0^{\mathrm{c}}$ \\
\hline
\end{tabular}

Values with different superscript letters in the same row were significantly different $(\mathrm{P}<0.05)$.

Table 2. Effect of temperature on growth, survival and food conversion ratio of 50 dah group of Nile tilapia at the end of temperature treatment (60 days) (Mean \pm SE).

\begin{tabular}{lccc}
\hline Parameters & $\mathbf{2 7}{ }^{\circ} \mathbf{C}$ & $\mathbf{3 5}^{\circ} \mathbf{C}$ & $\mathbf{3 7}{ }^{\circ} \mathbf{C}$ \\
\hline Total length $(\mathrm{cm})$ & $10.5 \pm 0.2^{\mathrm{a}}$ & $7.6 \pm 0.0^{\mathrm{b}}$ & $5.5 \pm 0.1^{\mathrm{c}}$ \\
\hline Total weight $(\mathrm{g})$ & $22.2 \pm 1.0^{\mathrm{a}}$ & $16.3 \pm 0.8^{\mathrm{b}}$ & $2.6 \pm 0.1^{\mathrm{c}}$ \\
\hline Growth rate (g/fish/day) & $0.35 \pm 0.0^{\mathrm{a}}$ & $0.26 \pm 0.0^{\mathrm{b}}$ & $0.03 \pm 0.0^{\mathrm{c}}$ \\
\hline Survival (\%) & $96 \pm 0.0^{\mathrm{a}}$ & $91 \pm 1.0^{\mathrm{b}}$ & $80 \pm 4.0^{\mathrm{c}}$ \\
\hline FCR & $2.3 \pm 0.0^{\mathrm{a}}$ & $2.6 \pm 0.0^{\mathrm{b}}$ & $3.1 \pm 0.0^{\mathrm{c}}$ \\
\hline
\end{tabular}

Values with different superscript letters in the same row were significantly different $(\mathrm{P}<0.05)$.

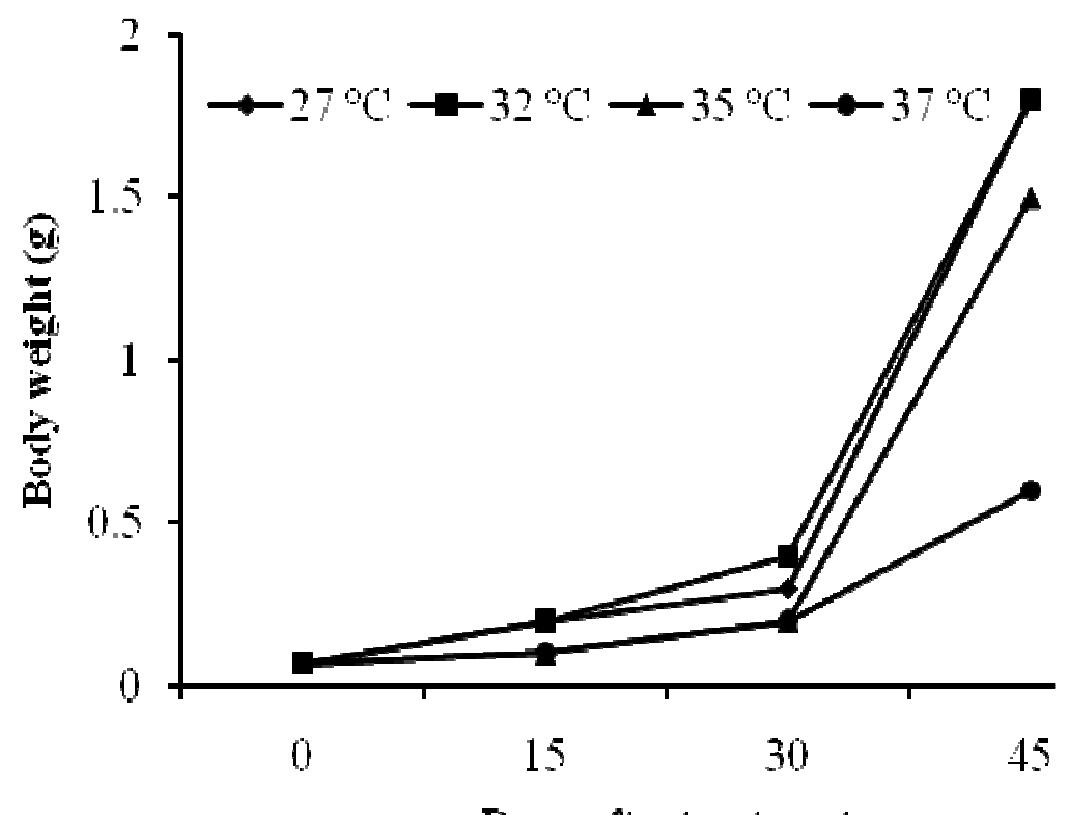

Days after treatment

Figure 1. Fortnightly mean weight of Nile tilapia juveniles in different temperatures during 45-day experimental period. Fish were exposed to different temperatures from 9 dah. 
N.P. Pandit and M. Nakamura / Our Nature (2010) 8: 219-224

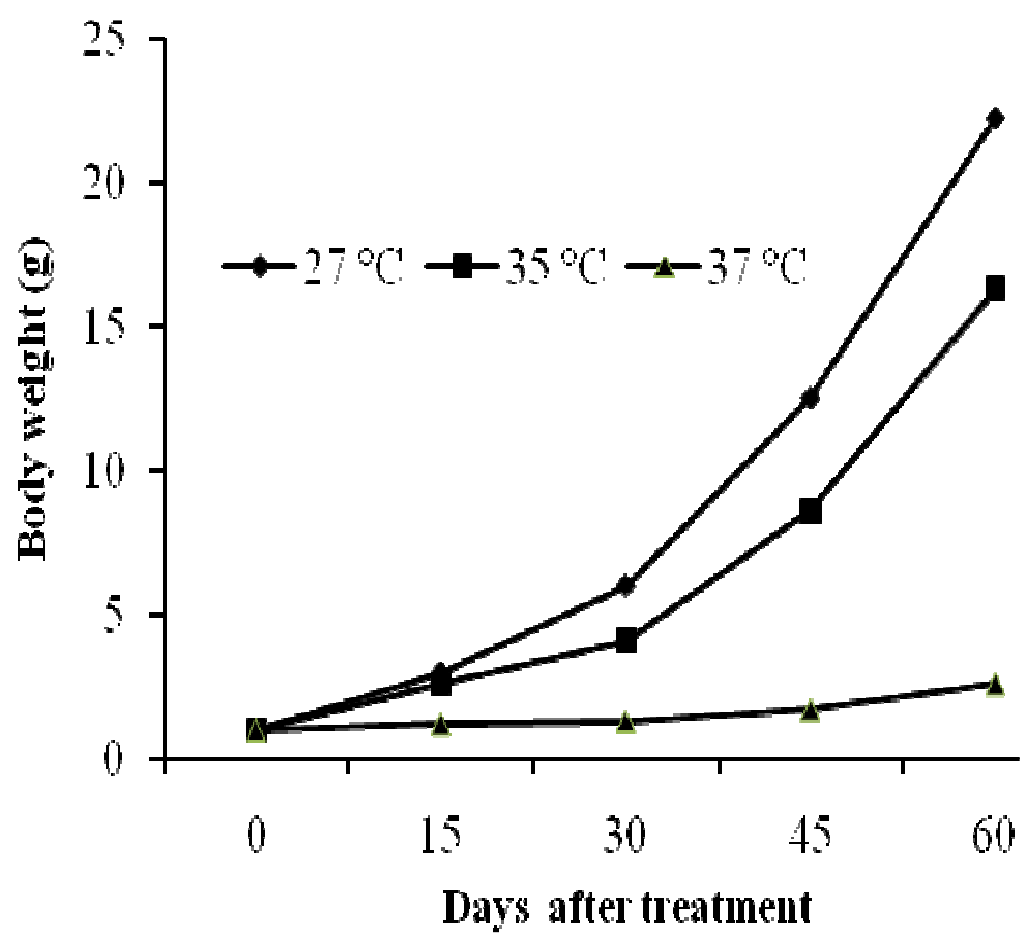

Figure 2. Fortnightly mean weight of Nile tilapia fries in different temperatures during 60-day experimental period. Fish were exposed to different temperatures from 50 dah.

high-temperature has detrimental and sometimes lasting effects on all age groups of fish. According to the IPCC (2001), global temperature will raise $2-6^{\circ} \mathrm{C}$ in this century. However, the summer temperature of shallow water bodies in many regions of Africa, Middle East, Asia and Australia might reach such predicted temperature much earlier. Thus, our findings indicate that predicted global warming scenarios will affect the survival and growth of shallow water species, and this might lead to mass extinction of the affected species. The present data only report the devastating effect of elevated temperature on hightemperature tolerant tilapia species. However, it is very likely that other teleosts will face the same fate if exposed to high water temperature as stated in the present study. Overall, it is possible to conclude that a temperature of $27-32^{\circ} \mathrm{C}$ is the optimum for growth of $O$. niloticus juveniles and fries; higher temperature $\left(35\right.$ and $\left.37^{\circ} \mathrm{C}\right)$ results in slow growth and increase mortality. Similar temperature optima have been noted in other members of the Cichlidae family. For example, O. mossambicus has an optimum temperature of growth at $30^{\circ} \mathrm{C}$ and Tilapia zilli has an optimum feeding temperature between 28.8 and $31.4^{\circ} \mathrm{C}$ (Stickney, 1986). However, the effect of water temperature on nutrient digestibility of the diet fed to the Nile tilapia still remains an important factor, which might play an important role in 
N.P. Pandit and M. Nakamura / Our Nature (2010) 8: 219-224

understanding the growth performance of the fish.

\section{Acknowledgement}

The authors are grateful to the Japanese Government (Monbukagaku-sho) Scholarship for providing research fund.

\section{References}

Anelli, L.C., C.D. Olle, M.J. Costa, F.T. Rantin and A.L. Kalinin 2004. Effects of temperature and calcium availabilty on ventricular myocardium from the neotropical teleost Piaractus mesopotamicus (Holmberg 1887Teleostei, Serrasalmidae). J. Therm. Biol. 29: 103-113.

Azevedo, P.A., C.Y. Cho, S. Leeson and D.P. Bureau 1998. Effects of feeding level and water temperature on growth, nutrient and energy utilization and waste outputs of rainbow trout (Oncorhynchus mykiss). Aquat. Living Resour. 11(4): 227-238.

Britz, P.J., T. Hecht and S. Mangold 1997. Effect of temperature on growth, feed consumption and nutritional indices of Haliotis midae fed a formulated diet. Aquaculture 152: 191-203.

Chatterjee, N., A.K. Pal, S.M. Manush, T. Das and S.G. Mukherjee 2004. Thermal tolerance and oxygen consumption of Labeo rohita and Cyprinus carpio early fingerlings acclimated to three different temperatures. J. Therm. Biol. 29: 265-270.

Chervinski, J. 1982. Environmental physiology of tilapias. In The Biology and Culture of tilapia (Eds. R.S.V. Pullin and R.H. Lowe-Mc Connell). ICLARM Conference Proceedings, vol. 7, Manila, Philippines. pp. 119-128.

Elliot, J.M. 1972. Rates of gastric evacuation in brown trout, Salmo trutta (L.). Freshwater Biol. 2: 1-18.
Gadowaski, D.M. and S.M. Caddell 1991. Effects of temperature on early-life-history stages of California halibut Paralichthys californicus. Fish Bull. 89: 567-576.

Hauser, W.J. 1977. Temperature requirment of tilapia. Calif. Fish Game 63(4): 228-233.

Hawkes, L.A., A.C. Broderick, M.H. Godfrey and B.J. Godley 2007. Investigating the potential impacts of climate change on a marine turtle population. Glob. Change Biol. 13: 923-932.

Intergovernmental Panel on Climate Change (IPCC) 2001. Climate change 2001: the scientific basis. Cambridge University Press, Oxford, UK.

Kamel, S.J. and N. Mrosovsky 2006. Deforestation: risk of sex ratio distortion in Hawksbill sea turtles. Ecol. Applications 16(3): 923-931.

Larsson, S. and I. Berglund 2005. The effect of temperature on the growth energetic, growth effic iency of Aractic charr (Salvelinus alpinus L.) from four Swedish populations. J. Therm. Biol. 30: 29-36.

Philippart, J-C. and J-C. Ruwet 1982. Ecology and distribution of tilapias. In The Biology and Culture of Tilapias (Eds. R.S.V. Pullin and R.H. Lowe-McConnell). ICLARM, Manila, Philippines. pp. 15-60.

Stickney, R.R. 1986. Culture of nonsalmonoid freshwater fishes. CRC Press, Boca Raton, FL.

Strüssmann, C.A., T. Saito and F. Takashima 1998. Heat-induced germ cell deficiency in the teleosts Odontesthes bonariensis and Patagonina hatcheri. Comparative Biochem. Physiol. 119A: 637-644.

Watanabe, T., T. Takeuchi, S. Satoh and V. Kiron 1996. Digestible crude protein contents in various feedstuffs determined with four freshwater fish species. Fish. Sci. 62: 278282. 